\title{
尿中ゲンチジシ酸量に就て, 附肝蔵機能との関係
}

\author{
日本医科大学薬理学教室（主任 西村菊次郎教授） \\ 坂本親行 \\ Chikayuki Sakamoto
}

\section{I) 緒 言}

生体汇サリチル酸 (サ酸) 又は其塩類を投与する そ, 尿中に 1 部は不変のま子遊離酸として, 他はグ ルクロン酸, グリシン等と結合し複合サ酸として, 刃 酸化せられでグンチジン酸 (ゲ酸) として排泝され る事は多くの人々によつて認められた。 ${ }^{2)-8)}$ 複合酸

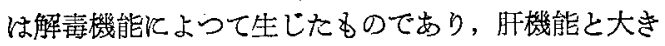
な関係を有する事が明らか汇されている。9 複合サ酸 と同様にサ酸より変化したゲ酸も肝機能と関係を有す るであるうと言う可能性は当然考光られてよい。ゲ酸 の排泄と肝機能との関係に関する文献は私の知るとこ ろで，黄燐及四塩化炭素肝障碍ラットルサ酸塩を注 射し，大の尿中にゲ酸の出現を見ないか又は著明に減 少せる事を認めたと言う Lutwak-mann ${ }^{7}$ の報告が

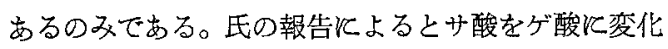
せしめる機能が肝と関係ある事を想方せるが，その採 沓法及反応法はゲ酸の多宾を推定するね止柰り定量的 に検索したものではなかつた。

及 Roseman ${ }^{5)}$ はゲ酸投与人尿には複合ゲ酸が認め られないのK反し, 酸曹達 (サ曹) 投与人尿に酸を 加光加水分解後のゲ酸量は加水分解前に比し全例に於 て增加している，即ち複合ゲ酸を認めたと述へていい る。Quilley ${ }^{6)}$ はサ酸塩投与のラ.ット尿より恐らくグ ルクロン酸結合によると思われる複合ゲ酸の少量を検 出したと述へている。但し両者共其数量は明示してい ない。

これ等の報告によると，サ酸は体内に於て遊離ゲ酸 そ変じ，更に複合ゲ酸に変ずるものであり，その変化 階梯は腹合睃より一段複雑と考克られるが, 複合ゲ 酸と肝機能との関係汇就て論及している文献はないよ ろである。そこで私はサ酸投与後尿中遊離ゲ酸量及複 合ゲ酸量を定量，比渂検討し，肝機能との関係を検索 せんとした。
先ず本実験適当な動物を選定する為，サ酸投与動 物よりのゲ酸の検出率飞就て見ると, Alpen ${ }^{4)}$ は人 サ酸経口投与乙，24-36 時間総尿採取し，投与量の. $1 \%$ 以下のゲ酸を, 又犬飞サ酸 $1 \mathrm{~g}$ を重曹水に溶解し 静注，30-36 時間総永採取し，4-5\%のゲ酸を， Roseman ${ }^{5}$ は人にサ曹経口投与し，24 時間総尿採取 し，2.5-2.7\%のグ酸を, ヌマウスに曹を腹腔内注射 乙,24 時間後動物をすりつぶし, $89 \%$ の゙酸を，Quilley ${ }^{6)}$ はラット飞サ曹を胃カテーテルで投与し，48時 間総尿を採取し，18-33.5\%のの゙酸を，Kapp ${ }^{81}$ は人 そサ曹経口投与し，尿中にゲ酸の排泄されなくなる运 定量し，4-8\%のグ酸を, 夫久検出している。以上の 成績を比較検討するに，ラット及マウス尿は豊富なゲ 酸を含有するが，動物が小さい為尿量が少く，本実験 の様汇 2 時間毎棌尿乙定量せんとする操作には不適 当である。人尿に於けるゲ酸の投与サ酸に対する検出 率研究者によつてまちまちであるが，Kapp に上れ ば相当な検出率を示している。然し他の動物に比し尿 量が多い為, 永中ゲ酸の含有率は低いと思われるし, 又本実験に於てはゲ酸と肝機能との関係を検索する時 飞, 人工的肝障碍及肝剔出をせねね゙ならず，かくの如 き事は人では不可能であるから，人尿についての実験 は不適当である。犬尿は投与酸に対し相当なダ酸検 出率を示し，本実験の操作汇対し尿量も適当であり， 従つて尿中ゲ酸の含有率も不足は無いる思われるし， 人工的肝障碍及肝剔出も可能である為最適之考兄られ る。故に実験動物には犬を選えだ。

ゲ酸の定量法に就ては, Accoyer ${ }^{10)}$, Mendioroz ${ }^{11}$, Gerald ${ }^{12)}$, Lowenthal ${ }^{13)}$;のフエノ一ル試薬による方 法, Benati ${ }^{14)}$, Mainardi ${ }^{15)}$ のゲ酸の還元作用をモり ブデン酸アンモンと応用した方法, Smith ${ }^{16)}$, Rosem$\mathrm{an}^{5)} の$ Folin-Ciocalteu ${ }^{17)}$ 試薬を応用した方法, Ungar $^{18)}$, Kleckner ${ }^{1)} の$ Ultravioletspectrophotometry 亿よる方法, Quilley ${ }^{6)}$, Nanninga ${ }^{19)} の$ paper- 
$-48-(342)$

chromatography 飞よる方法, Rutkowski ${ }^{20)} の$ Iodometry Kよる方法等があるが，能勢 ${ }^{21}$ はこれ等の数 種を検討し：いずれす高度の技術を要するか，又は奶 害物質の充分な除去が約束されない限り尿光の応用は 困難なる事を認め，ゲ酸の還元作用を燐モりブデン酸 飞応用した新方法を報告し，人及家鬼にこの方法を用 いた。私は犬尿に就て能勢氏反応を検討したが，妨害 物質多量の為犬には応用が困難な事を知つた。

Lutwak-mann ${ }^{2}$ はサ酸塩注射後のラット尿飞苛性 曹達 (苻曹) 溶液を滴下すると褐色より黒色江変化す る物質のある事に著目し，これを尿よりエーテルルて 抽出乙白色粉末を得，これがゲ酸なる事を認めた。更 沃ゲ酸と苛曹溶液との旺色反応の色濃度により尿中ゲ 酸量の多寄を推定する方法を用いた。

このゲ酸のアルカリ呈色反応（ゲ酸旺色反応）が犬 尿中ゲ酸の定量化用い得るならぼ，其操作の簡易であ る事の故に，以後の実験便であると考えたので，私 はゲ酸是色反応飞検討を加克，犬尿中ゲ酸の定量江用 认得る方法を見出し，更汇其定量法を用いて犬沓中ゲ 酸量と肝機能との関係孝検案した。

向私は酸が苛曹溶液と呈色反応を示さない事を実

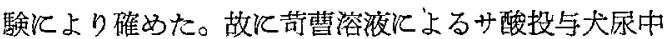
ゲ酸定量法は，同時汇尿中出現する遊離サ酸汇よっ て妨害せられる事はない。

\section{II）基 礎 実 駧}

Lutwak-mann はサ酸注射ラット尿数 cc 飞 10\%塩 酸を加兄て酸性化乙， 3 倍容のエーテルを加克て振 盜，ゲ酸を抽出し，エーテル相汇数 $\mathrm{cc}$ の封曹溶液を 加党て振蕰，ゲ酸を再抽出と同時飞呈色せしめて苛曹 溶液相が赤色より褐色に変色してゆくゲ酸是色反応の 濃淡を観察し，尿中ゲ酸量の多宣を推定した。

犬尿に於ても同様にエーテルにて抽出し，これ亿苛 曹溶液を加兄振晹, ゲ酸を再抽出と同時にゲ酸呈色反 㐫を起さしめ：これを比色定量し得るならば其操作は 簡易であろう事が想像される。然し Lutwak-mann の

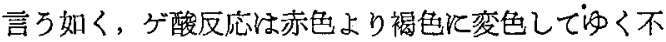
安定なるのであり，そのま」では比色定量応用する 事は出来ない。先ず色調を安定させなければならな い。私はゲ酸呈色反応が各条件下に現わす色調変化の 性質を検討し，その安定となるへさき条件を兒出さんと Lた。
A）安定な色調を得る為の実験
1）各種規定苛曹溶液内ゲ酸呈色反応の時間的変化

1/1000 M より $1 \mathrm{M}$ 迄の苛曹溶液を作りこれ沃ゲ 酸を投入， $10 \mathrm{mg} / \mathrm{d} l$ となし，混和呈色せしめて後時 間を測定し作ら比色測定した。比色には日立製光電比

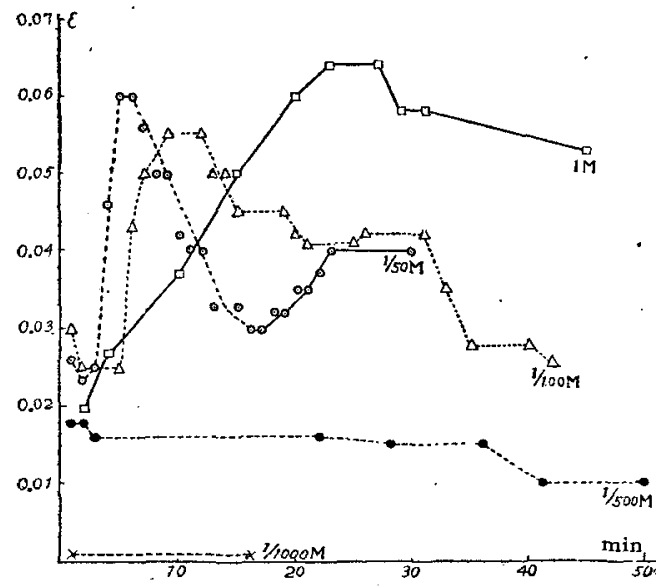

第 1 図

各種規定苛曹溶淮内ゲ酸呈色反灾の㭙間的変化 …………...赤色反応，—褐色反芯 ゲ 酸濃度 $: 10 \mathrm{mg} / \mathrm{d} l$

色計を用いた。比色条件：フィルター：コバルト（波 長 $430-440 \mathrm{~m} \mu$ ), セル : $3 \mathrm{~mm}$, 対照 : 水, 室温 : $24^{\circ} \mathrm{C}$ 成績江第1図江示す。

各種規定荷曹溶液内ゲ酸呈色反応山かなり多様の变

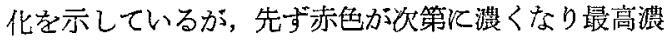

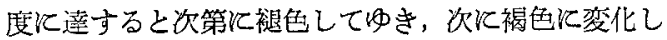

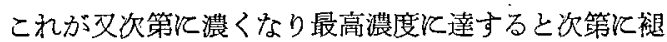
色してゆく。即ち初めの赤色反応之後の褐色反空と飞 分ける事が出来る。例完ば第1図 1/50 M の曲線はこ れを示す。

1/1000，1/500，1/100 M は総て赤色反応であり， ア ルカリ低濃度の為 50 分以内には褐色反応は出て来な かつた。1/1000，1/500 M で在色調柱定であるが色 灌度が低く此色汇は不適である。1/100 M では色濃度 は高いが不安定である。1/50 M では赤色，褐色両反

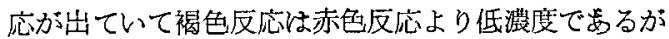

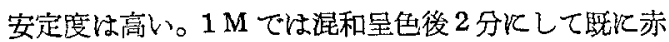
色反応は褪色乙褐色反応が出て来ている。褐色度応怯 高濃度を示し安定度も比較的高い。

本実験及爾余の実験により，ゲ酸呈色反灾は次の様 な㥧向を有する事を知り得た。これを做構圈として第 2 図江示す。 


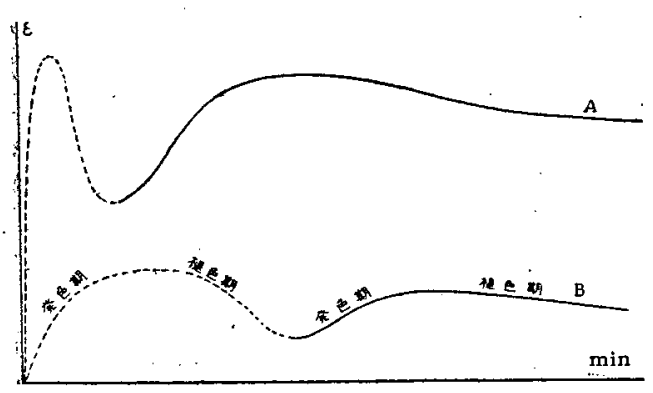

第 2 図

ゲ酸呈色反応の仮構図

: 赤色反店——褐色反応

A：アルカリ高濃度，B：アルカリ低濃度

i）赤色反応怯褐色反応上り迅速に経過し，（此色 飞短所)，且つ高濃度である。(比色飞長所)。

ii）アルカリ謴度が高い場合は低い場合より反応

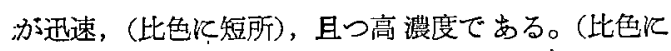
長所)。

iii）赤色反応も裪色反応子発色期は迅速, (此色に 短所)，祓色期は緩慢である。(比色飞長所)。

ゲ酸呈色反応のこれ等の性質中，比色偟長所を生か 乙，短所を除き，高濃度にして安定なる色調を得んと の方針のもとに以後の実験を進めた。

2) 苛曹澱粉溶液内ゲ酸呈色反応の時間的変化 赤色反応の高濃度を利乙, 反応経過時間を渐粉溶液 聇て逮延せしめ, 此色儿適当な色調を得る目的にて本

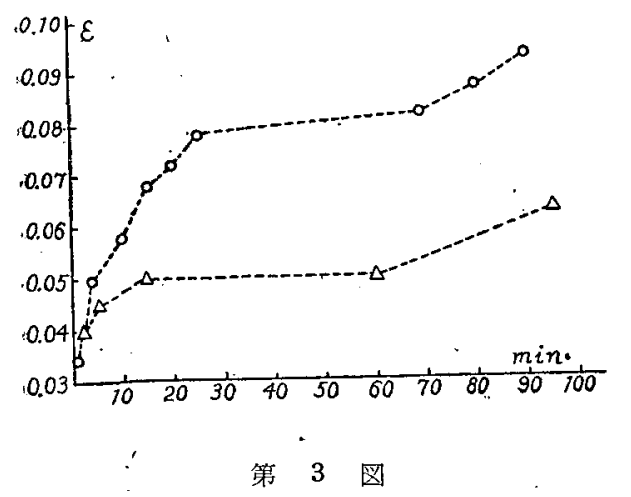

苛曹澱粉溶液内 ゙酸呈色反忘の時間的变化 ……赤色反応, $\bigcirc$ : 第 1 例, $\Delta$ : 第 2 例

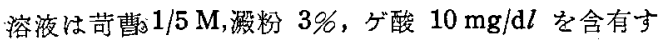

\section{実験を試みた。}

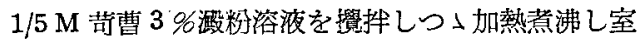
温飞て放泠, これとゲ酸を加え $10 \mathrm{mg} / \mathrm{d} l$ となし混和 呈色せしめて後，時間を測定し乍ら比色測定した。本
実験は 2 例汇就き行つた。比色条件：フイルター：コ

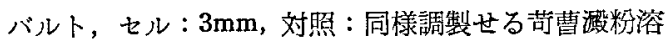
液，室温 : $30^{\circ} \mathrm{C}$ 。成績は第 3 図々示す。

同一例飞就ては色調の安定する時間を有するのであ るが, 各例の色濃度に可成の差があり比色定量には不 適である。

3）低温内ゲ酸呈色反応の時間的変化

2）と同様赤色反応の高濃度を利し，反応経過時間 を低温とて遅延せしめ，此色に適当な色調を得んとし て本実験を試みた。

$1 / 500,1 / 100 ， 1 / 50 \mathrm{M}$ の苛 曹溶液炕ゲ酸を投入, $10 \mathrm{mg} / \mathrm{d} l$ となし混和呈色せしぬ，直ちと泠蔵庫 $\left(9^{\circ} \mathrm{C}\right)$ に入れ，時間を測定しながら冷蔵庫より被検液を取出 して直ちに比色測定した。比色条件：フイルター：コ バルト, 女ル: $3 \mathrm{~mm}$, 対照: 水, 室温: $24^{\circ} \mathrm{C}$ 。成續は

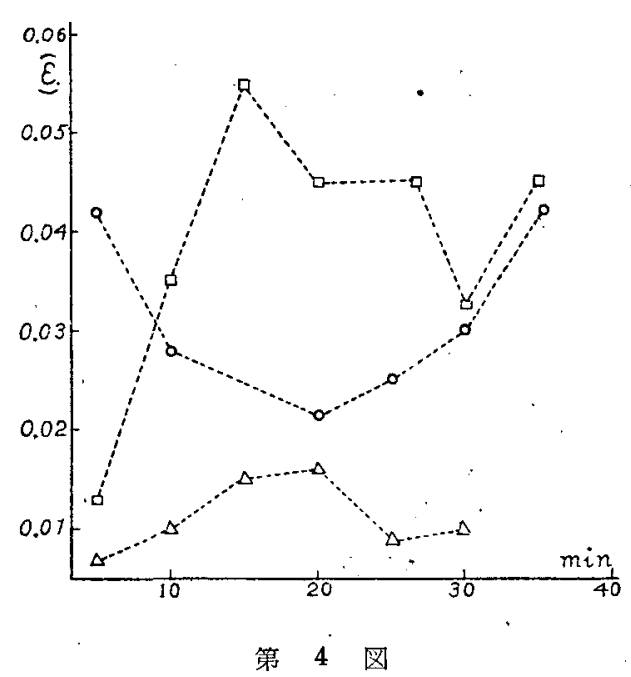

低温内 $\left(9^{\circ} \mathrm{C}\right)$ ゲ酸呈色反忘の時間的変化 ……… : 赤色反忘, 苂曹濃度 $: 0: 1 / 50 \mathrm{M}$, $\square: 1 / 100 \mathrm{M}, \Delta: 1 / 500 \mathrm{M}$, ゲ酸濃度 : $10 \mathrm{mg} / \mathrm{d} l$

第 4 図炡示す。

$1 / 50 \mathrm{M}$ 溶液は室温内ならば 20 分以内以褐色反応 飞移行すべきなのに本実験で注 35 分後も向赤色反応 のまつであつた。1/50 M 1/100 M 上りも色濃度が 低い。これは低温の為常温時と㤨つた反応態度を示 す故と思われた。全例不安定にて比色定量には不適で あつた。

4) 沸騰温浴後ゲ酸呈色反応の時間的変化

呈色反応を高熱にて促進すれば，短時間内に反応の 最終的段階に到達せしめ得て安定なる色調を得べしと 考劣，この実験を試みた。 
$-50-(344)$

$1 / 5 \mathrm{M}$ 苛曹溶液にゲ酸を投入 $20 \mathrm{mg} / \mathrm{d} l$ とな乙混和， 呈色開始して各 $10,30,60$ 分後より，20分間沸滕温 浴し，室温飞て放泠時間を測定しながら比色测定し た。沸騰温浴は 20 分以上経続すると沈濒を生ずる為 20 分を適当とした。比色条件：フイルター：コバル

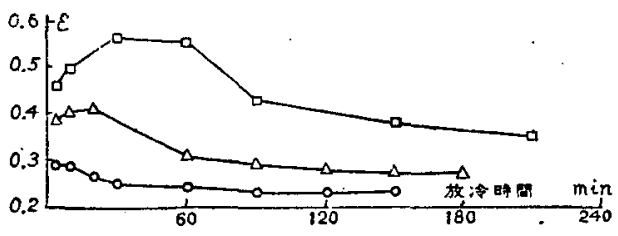

第 5 図

势騰温浴後ゲ酸呈色反応の時間的変化 ：褐色反応， 口：反応啳 10 分で温浴， $\Delta$ : 反応後 30 分で温浴, $\mathrm{O}$ : 反忘後 60 分で温 浴, 苛曹濃度 : $1 / 5 \mathrm{M}$, ゲ酸泳度 : $20 \mathrm{mg} / \mathrm{d} l$, 沸騰 温浴 : 20 分

ト, セル: $10 \mathrm{~mm}$; 対照: 水, 室温 : $13^{\circ} \mathrm{C}$ 。成續は第

5 図に示宁。

呈色反応閏始より沸騰温浴を始める迄の時間の相異 によつて色濃度が暴り，又放冷する時間の経過飞従つ て色濃度が変化する。即ち二つの条件関聯して不安 定な色調となる為比色定量には一㕌不適と考えた。

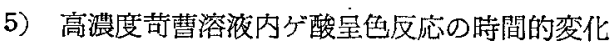

高濃度苛曹溶液内では赤色反応は速か煺色し，高 濃度の褐色反応現れ，ての能色時はゲ酸呈色反応系中 最も安定度の高い傾向を有するので，この部を検討せ えとして $1 / 5 \mathrm{M}$ 及 $1 \mathrm{M}$ 苛曹溶液に就て試みた。

i) $1 / 5 \mathrm{M}$ 苛曹溶液の場合

$1 / 5 \mathrm{M}$ 苛曹溶液にゲ酸を投入し $20 \mathrm{mg} / \mathrm{d} l$ となし， 混和星色せしめて後, 時間を测定しながら比色測定し

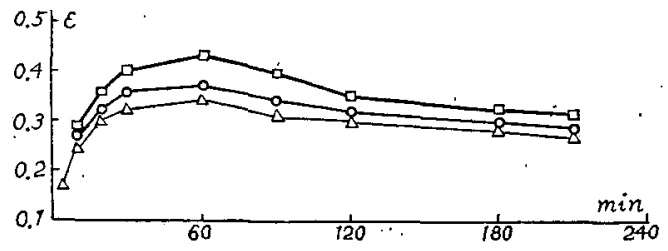

第 6 図

$1 / 5 \mathrm{M}$ 节曹溶液内ゲ酸呈色反忘の時間的変化 : 褐色反心， $\square$ : 第 1 例， $\bigcirc$ : 第 2 例, $\triangle:$ 第 3 例, ゲ要濃度 $: 20 \mathrm{mg} / \mathrm{d} l$

た。本実験は 3 例に就き行つた。比色条件：フイルタ 一: コバルト, セル: $10 \mathrm{~mm}$, 対照: 水, 室温 : $13^{\circ} \mathrm{C}$
成續は第 6 図に示高。

同一例の星色反応の時間的変化飞於ては螁色時安定 度の高い色調を得たが, 各例の色浪度には可成りの差: があり，比色定量には不適であつた。この差忹荅曹と ゲ酸を混和する時の振湓回数及その強度にる原因する ๖のと思われ，ゲ酸呈色反応は各条件に極めて銧敏に 影響を被るるのと考えられた。

ii） $1 \mathrm{M}$ 苛曹溶液の場合

この様沃ゲ酸呈色反念は各条件の僅かな変化に対し てる鋭敏に影響を被るので，例学試験管内にて安定な 色調の呈色反心を造り得ても，畊物実験の場合は尿に エーテルを加え強振璗する等の影響が加わるので, 単: に試験管内の奏験とは異つた色澧度を旺するのであ る。

これらの影響を雇虑して尿中央験の条件に近からし めんが為に，本実験に於てもゲ酸を苛曹溶液と混和呈 色せしめる時にエーテルを加え，且つ分液漏斗を用い 200 回強振璗する事にした。

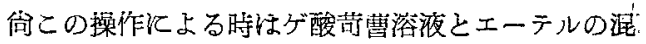
合液を分液漏斗にて振䔽している間に, エーデルが微 量乍らゲ酸苛曹溶液に溶解し，ゲ酸曹曹溶液の液量が: それだけ増加するので, 若し振溋前から予定量のゲ 酸草曹溶液を使用する時は，振燙後は予定量以上にな り，任意の濃度のゲ酸苛曹溶液を比色測定する事が出 来なくなる。

そこで振盪前はゲ酸苛曹液量を予定の量より少な目 にした。然る時は振湓後エーテルの溶解によりゲ酸苛:

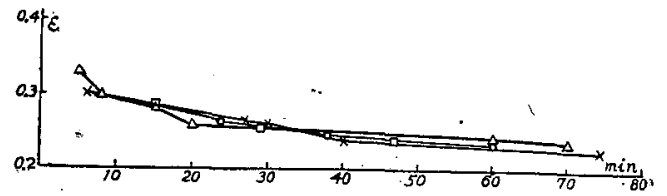

第 7 図

$1 \mathrm{M}$ 苛曹溶液内ゲ酸呈色反心の時間的変化 $-\ldots$ : 褐色反応, $\Delta$ : 第 1 例， $x$ : 第 2 例,

$\square$ : 第 3 例， $\bigcirc$ : 第 4 例，ゲ酸䕃度 $: 5 \mathrm{mg} / \mathrm{d} l$

曹溶液の量か増加してる予定の量に達せぬので，振燙: 後の苛曹溶液を分滩漏斗より出した後, これに水を加; えて予定の量としたので任意の濃度のゲ酸苛曹溶液を” 比色測定する事が出来た。

$5 \mathrm{M}$ 苛曹溶液 $10 \mathrm{cc}$ 飞水文加方て $40 \mathrm{cc}$ となし， これに $100 \mathrm{mg} / \mathrm{d} l$ ゲ酸 $2.5 \mathrm{cc}$ 学加党, 混和星色後值

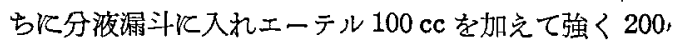

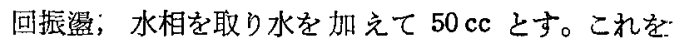



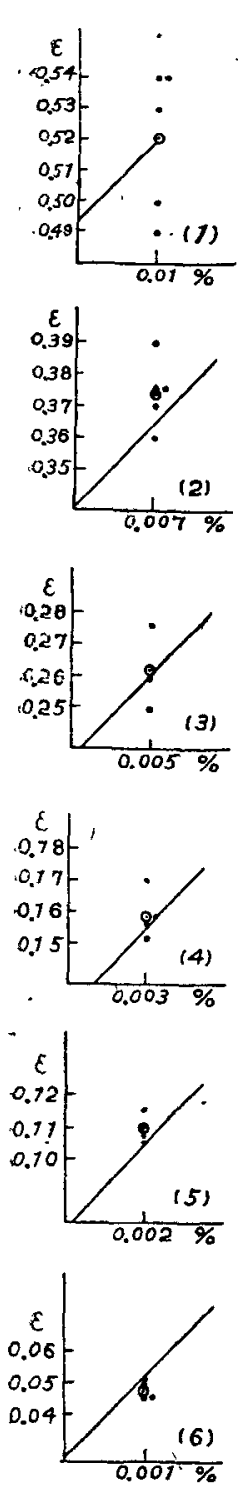

第 8 図の昖大図

$90 \mathrm{cc}$ とす。

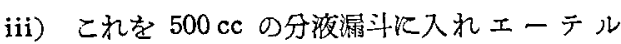
$100 \mathrm{cc}$ を加觉約 200 回強振䔽。

iv）水相を取りメスデリンデルに入れ水を加え 100 cc とす。静汃混和。これを夫々 $1,2 ， 3 ， 5 ， 7$ ， $10 \mathrm{mg} / \mathrm{d} l$ ゲ酸の $1 \mathrm{M}$ 苛曹浴液とす。

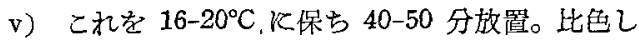
標準グラフを作る。

$5 \mathrm{mg} / \mathrm{dl}$ ゲ酸 $1 \mathrm{M}$ 苛曹溶液と す。静かに混和, その後の時間を 測定しながら比色測定した。本実 験隹 4 例汇就き行つた。比色条件 :フイルター：コバル，セル: $25 \mathrm{~mm}$, 対照: 水, 室温 : $20^{\circ} \mathrm{C}$ 。 成績第 7 図江示す。

アルカリ強度の為呈色後 5 分飞 して既に褐色反応の螁色期であ り, 呈色後 40 分より 50 分の間 が略一定の色濃度杂示乙, 而为 4 例と各期を通し略同一色濃度を 示しているのて，40 分より 50 分 の間が比色定量に応用可能なる部 分上教えた。この様に各例共略一 定色調が得られた理由は高澧度の アルカリで回数多く強振盪した 為, 略極限迄反応が進んだ事，振 鳁の回数及强度を一定した事によ り各例間の反忘進行度の差が少く なつた事によるものと思われる。

\section{B） 犬尿中ゲ酸定量法を決定 する為の実験}

1) 標準グラフ作製方法

$1 \mathrm{M}$ 苻曹溶液内ゲ酸呈色反応に て安定色を得たのでこの方法に 準拠して標準液を造つた。又この 呈色反応は温度の影響も鋭解に被 るので，放置時の温度の範囲も規 定した。

i) $2.5 \mathrm{M}$ 苛曹溶液 $40 \mathrm{cc}$ 妾メ スチリンデルに入れ水を加え約 80 $-90 \mathrm{cc}$ とし混和す。

ii) これに $100 \mathrm{mg} / \mathrm{d} l$ ゲ酸溶液 を夫々 $1,2,3,5,7,10 \mathrm{cc}$ 加 党静名江混和。この時の液量は約，

\section{(1)}




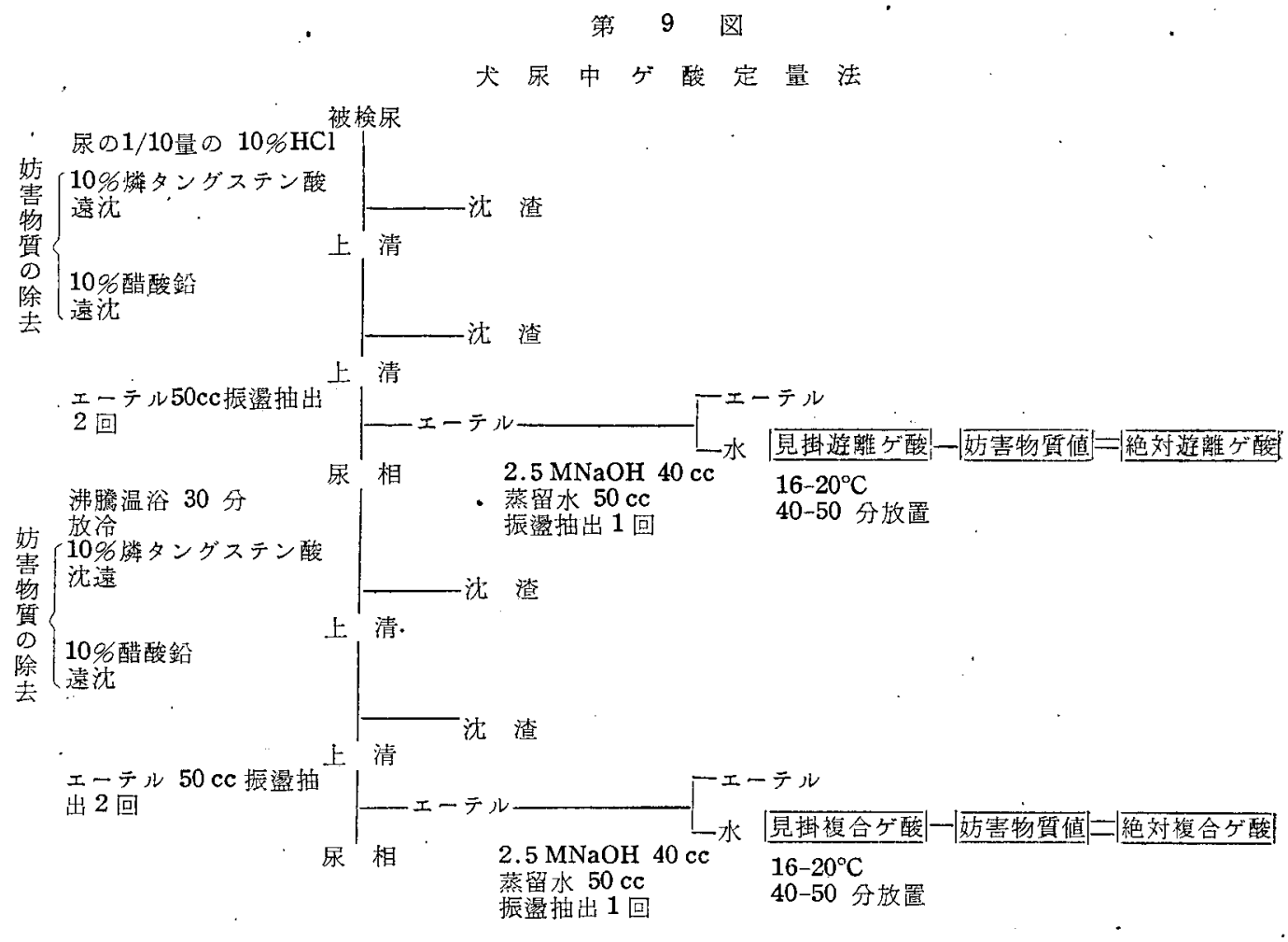

比色条件：室温，フイルター：コバルト (430-440 $\mathrm{m} \mu)$, セル: $25 \mathrm{~mm}$, 対照: $1 \mathrm{M} \mathrm{NaOH}$

沈澱を.2000 回転 5 分間遠心沈兴し，上清を取り尿の $1 / 2$ 量の $10 \%$ 醋酸鉛を加光混和し，生ぜる白色沈澱 を同様に遠心沈溊し，上清を取り分液漏斗泟入れエー テル $50 \mathrm{cc}$ を加完，200回強振洫抽出，これを 2 回操 返し，静置してェーテル相と尿相とに分離す。溶媒に よる溶解度の差により, 遊離ゲ酸はエーテル相に, 複 合ゲ酸は尿相汇含まれている。

遊離ゲ酸 : $2.5 \mathrm{M}$ 苛曹溶腹 $40 \mathrm{cc}$ 亿水を加光約 $90 \mathrm{cc}$ となし混和す。これをエーテル相に加党 200 回強振 淘抽出す。この時ゲ酸は苛曹溶液内再抽出せられる 之同時呈色反応を起し，赤色上り速か汇褐色汇変化 してゆく。この操作は 1 回㐳て充分でめる。静置して エーテル相と苛曹溶液相に分離す。苦曹溶液相を取り 水を加党 $100 \mathrm{cc}$ となし静か汇湜和し，16-20 $\mathrm{C}$ 亿保 ち 40-50 分放圈す。これを比色測定し, ゲ酸標準グ ラフにより見掛遊離ゲ酸量を求め, これより妨害物質 值（後述）を差引き絶対ゲ酸㽚を算定する。比色条件 : 室温：フイルター：コバルト(波長 430-440 m セル : $25 \mathrm{~mm}$, 対照 : $1 \mathrm{M}$ 寺暼溶没。

複合攵酸：尿相（塩酸酸性）を 30 分沸腾温浴し,
これを放冷して加水分解を行い，複合ゲ酸を避離ゲ酸 にして後遊離ゲ酸と同様泟宣する。

3） 犬原汸於ける妨害物質值

犬永をそのま」この定量法泣りグ酸を定量する場 合，尿中《監色の呈色反応を起す物質，即ち妨害物質 が出現する。私け種々の組合せとて燐タングステン 酸，醋酸鉛，硝酸銀を用いて尿を脱色した後奻害物質 を定量して，その除去力を検討し，最も強力と思われ る方法を本定量法中に採用した。然しこの方法に於て す何妨害物質を僅かながら認めたので，これと検討を 加壳た。好害物䨘値は主に尿量関係を有し，採尿迄 の時間及尿色核関保が少いと思われたので，無処置 正常犬より採尿し本定量法により好害物䆩を定量し， 尿量注対する妨害物質值を比較検討した。成綘は第 2 表に示す。

平均值に於て尿量 $10 \mathrm{cc}$ 迄は遊離妨害物 質值 0.04 $\mathrm{mg}$, 複合妨害物䆩值 $0.15 \mathrm{mg}$, 夫以上 $20 \mathrm{cc}$ 迄惊遊 離妨害物筫值 $0.08 \mathrm{mg}$, 複合妨害物質值 $0.12 \mathrm{mg}$ を認 めた。

本成結飞就て考察すると，遊離妨害物賔値は尿量飞 
比例するが，複合妨害物兵值は尿量と関係を有せ欧る のと考克られ，尿量と複合妨害物筫值の関係に就ては 侣令後模討の余地加ある。

定量汇際しては正確を期する為, 遊離に於ては見掛

第 2 表

犬承に於ける站害物質值

\begin{tabular}{|c|c|c|c|c|c|}
\hline \multirow{4}{*}{$\begin{array}{l}\text { 実 } \\
\text { 験 } \\
\text { 番 } \\
\text { 号 }\end{array}$} & \multirow{4}{*}{$\begin{array}{l}\text { 各 } \\
\text { 例 } \\
\text { の } \\
\text { 尿 } \\
\text { 量 } \\
\text { CC }\end{array}$} & \multicolumn{4}{|c|}{ 尿量飞よる分類 } \\
\hline & & \multicolumn{2}{|c|}{ 自 0 至 $10 \mathrm{cc}$} & \multicolumn{2}{|c|}{ 白 10.1 至 $20 \mathrm{cc}$} \\
\hline & & 逰 離 & 複 & 遊 離 & 䉯 合 \\
\hline & & \multicolumn{4}{|c|}{ 妨害物質值：mg } \\
\hline 1 & $20.0^{\circ}$ & & & 0.20 & 0.04 \\
\hline 2 & 20.0 & & & $0 .-$ & 0.04 \\
\hline 3 & 20.0 & & & 0.04 & 0.36 \\
\hline 4 & 20.0 & & & 0.16 & 0.12 \\
\hline 5 & 8.5 & $0 .-$ & 0.10 & & \\
\hline 6 & 17.0 & & & 0.04 & $0 .-$ \\
\hline 7 & 20.0 & & & $0 .-$ & 0.18 \\
\hline 8 & 20.0 & & & 0.04 & 0.40 \\
\hline 9 & 4.3 & 0.02 & 0.26 & & \\
\hline 10 & 20.0 & & & 0.10 & 0.06 \\
\hline 11 & 20.0 & & & 0.20 & 0.20 \\
\hline 12 & 5.6 & $0 .-$ & 0.20 & & \\
\hline 13 & 4.4 & 0.06 & 0.04 & & \\
\hline 14 & 10.0 & 0.10 & $0 .-$ & & \\
\hline 15 & 20.0 & & & 0.08 & $0 .-$ \\
\hline 16 & 20.0 & & & $0 .-$ & $0 .-$ \\
\hline 17 & 20.0 & & & 0.10 & $0 .-$ \\
\hline 18 & 7.2 & 0.06 & 0.30 & & \\
\hline 総 & 量 & 0.24 & 0.90 & 0.96 & 1.40 \\
\hline 平 & 均 值 & 0.04 & 0.15 & 0.08 & 0.12 \\
\hline 最 & 大 值 & 0.10 & 0.30 & 0.20 & 0.40 \\
\hline 最 & 小 值 & $0 .-$ & $0 .-$ & $0 ;-$ & $0 .-$ \\
\hline
\end{tabular}

䒠験期間 自 昭 29.10.1 至 29.12.23

ゲ酸量より, 尿量 $10 \mathrm{cc}$ 迄は $0.04 \mathrm{mg}$ 夫以上は尿量
$10 \mathrm{cc}$ 增す每行 $0.04 \mathrm{mg}$ 加算した妨害物質値を差引 き絶対づ酸量を求めた。複合攵酸に於ては尿量に関係 なく見掛ら゙酸量より常に $0.15 \mathrm{mg}$ の妨害物質值を差 引き絶対ゲ酸量を求めた。

4) 刜滕温浴時間と複合ゲ酸分解度との関係

複合ゲ酸を加水分解して遊離ゲ酸とする為に尿を酸. 性下沸滕温浴するが，その所要時間短きときは複合 ゲ酸を完全㳄分解し尽せず，長き飞過ぎる時は時間の. 不経珮のみならず妨害物㙺が堌量してくる恐れがあ る。この為沸勝温浴時間ほ最短にして立分である事 が理想である。

正常犬汇曹 $500 \mathrm{mg}$ 皮下注射後 4 時間 総尿採取: し，本定量法の操作により遊離グ酸を除去したる尿を 3 等分乙, 沸騰温浴時間を夫々 $15,30,60$ 分とし, .其他は本定量法と同操作に上り複合ゲ酸量を求めこれ を検討した。成績は第 3 表に示す。

複合ゲ酸は沸騰温浴時間 15 分より 30 分迄は増量 て，30 分より 60 分迄は殆ど差を認めない。故に 30 : 分を以て最短にして充分なる淽滕温浴時間とし本定量 法中に採用した。

5） 犬尿飞於ける添加試験

以上を以て本定量法の操作上の検討を終了したが最 後仗本定量法の正確度を見る為にこの実験を行つた。

$$
\text { 第 } 3 \text { 表 }
$$

、尿の沸騰温浴時間と複合ゲ酸分解度との関係

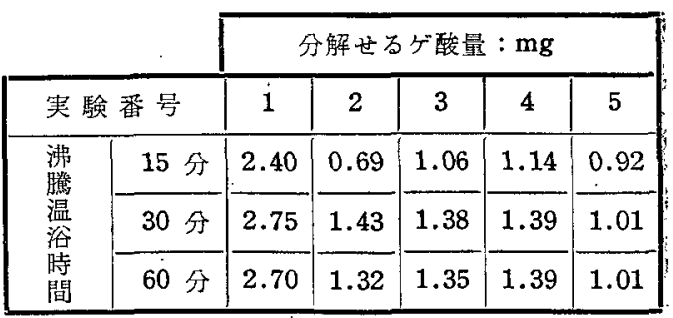

i）遊離ゲ酸定量法の正確度を見る為に，無処置正 常大尿 $10 \mathrm{cc}$ 亿ゲ酸を $4 \mathrm{mg}$ 添加混合し; 遊離ゲ酸. 定量法を用いて添加ど酸を定量した。

ii）複合ゲ酸定量法の正確度を見る為無処置 正 常犬尿 $10 \mathrm{cc}$ 红予め遊離ゲ酸定量操作を施した後ゲ酸 を $4 \mathrm{mg}$ 添加混合し, 複合ゲ酸定量法を用いて添加ゲ 酸を定量した。成續は第4 表に示す。

尿をとのま」にて定量した場合，即占ｉ）の場合は 最高検出率 $102.0 \%$ 最低検出率 $97.8 \%$ 平均検出率. $99.2 \%$ であり，尿を 30 分沸腾温浴した場合，即ら ii）の場合は最高検出率 $96.8 \%$ 最低検出率 $88.8 \%$ \% 
$-54-(348)$

平均検出率 94.7\%である。依て本定量法核実用に供 乙得べき正確度を有するものと認めた。

\section{1) 実験材料及方法}

\section{III）動 物 実 験}

実験動物: $10.0 \mathrm{~kg}$ 内外の牝犬を用いた。

サ曹投与 : $10 \%$ サ曹水溶液 $5.0 \mathrm{cc}$ (サ曹 $500 \mathrm{mg}$ ) 学皮下注射す。

第 4 表

犬录に於ける添加試験

添加ら゙酸 $4 \mathrm{mg}$ 尿量 $10 \mathrm{cc}$

\begin{tabular}{|c|c|c|c|c|}
\hline \multirow{2}{*}{$\begin{array}{l}\text { 英 } \\
\text { 験 } \\
\text { 番 } \\
\text { 号 }\end{array}$} & \multicolumn{2}{|c|}{$\begin{array}{l}\text { 尿をそのまま } \\
\text { てて定量 }\end{array}$} & \multicolumn{2}{|c|}{$\begin{array}{l}\text { 层を } 30 \text { 分沸騰 } \\
\text { 温浴 後定量 }\end{array}$} \\
\hline & 検出 $\mathrm{mg}$ & 检出 \% & 検出 $\mathrm{mg}$ & 枱出 $\%$ \\
\hline 1 & 3.91 & 97.8 & 3.55 & 88.8 \\
\hline 2 & 3.95 & 98.8 & 3.83 & 95.8 \\
\hline 3 & 3.95 & 98.8 & 3.87 & 96.8 \\
\hline 4 & 3.94 & 98.5 & 3.83 & 95.8 \\
\hline 5 & 4.08 & 102.0 & 3.85 & 96.3 \\
\hline & \multicolumn{4}{|c|}{ 平 } \\
\hline & \multicolumn{2}{|c|}{$99.2 \%$} & \multicolumn{2}{|c|}{$94.7 \%$} \\
\hline
\end{tabular}

採尿：ネラトンカテーテル又は金属カテーテルにて サ曹投与後 4 時間迄 2 時間毎に行う。

氺の pH 測定：pH Test Paper（東洋滤紙製）学用 5 。

ゲ酸定量法：本定量法を用う。

2）正常犬尿中ゲ酸量

a) 犬に加わる諸条件の尿中ゲ酸量に及ぼす影響 実験中犬に加わる諸条件の影響による尿中ゲ酸量の 動摇範囲を知る為次の如く実験を行つた。

i) サ曹負荷回数の影響

同一犬にサ曹初回注射後一週閒以上の間隔を固き, 既に尿中ゲ酸が排泄せられていないのを確めた上再度 サ曹を注射して初回及再度目荷時尿中ゲ酸舅を定量し 比較した。成績は第 $5,6,7$ 表に示す。

遊髉ゲ酸のサ曹再度負荷時平均值注初回負荷時平均 值に比し, 夏季背位固定の場合注僅に娍少, 夏季非固 定の場合は僅汃増加, 秋季非固定の場合は著明に減 少す。複合ゲ酸のサ曹再度負荷時平均值は初回負荷時 平均值に比し, 夏季背位固定, 夏季非固定, 秋季非固 定の総てに於て著明に減少す。即占等曹度負荷時に 於ては遊離ゲ酸は減少の傾向を有し, 複合ゲ酸ふ常に
減少す。斯様に再度負荷時には尿中ゲ酸量は甈に減少 の傾向を有しているのであるから，尿中ゲ酸量を研究 するにはサ曹初回負荷尿就て行うが罙当と考方る。

而しこの減少の原因はサ曹負荷回数の増加によるる のとは限らず，初回負荷より再度負荷迄の犬小屋に飼 養する期間によるものか，犬の食料に関係するものか は検討を要する問題で，今後の研究に待つ。

\section{ii）固定の影響}

犬を 4 時間も固定すると，かなり苦闗するのでその 影響知る為背位固定のま しその他の時は非固定のま」の実験を行い尿中ゲ酸量 を定量し比較した。成結は第5，6表に示す。

遊離ゲ酸及複合ゲ酸の初回負荷平均値及再度負荷平 均值は共江夏季非固定より夏季背位固定の方が僅に多

$$
\text { 第 } 5 \text { 表 }
$$

正常犬尿中ゲ酸量 夏季背位固定の場 合

\begin{tabular}{|c|c|c|c|c|c|c|c|c|c|}
\hline 号 & $\begin{array}{l}\text { 注 } \\
\text { 射 } \\
\text { 回 } \\
\text { 数 }\end{array}$ & $\begin{array}{c}\text { 実 } \\
\text { 験 } \\
\text { 月 } \\
\text { 日 }\end{array}$ & $\begin{array}{l}\text { 室 } \\
\text { 温 } \\
{ }^{\circ} \mathrm{C}\end{array}$ & $\begin{array}{l}\text { 菢 } \\
\text { 点 } \\
\text { 後 } \\
\text { क } \\
\text { 時 } \\
\text { 間 } \\
\mathrm{h}\end{array}$ & $\mathrm{pH}$ & $\begin{array}{l}\text { 原 } \\
\text { 量 } \\
\mathrm{cc}\end{array}$ & $\begin{array}{c}\text { 游 } \\
\text { 離 } \\
\text { ゲ } \\
\text { 酸 } \\
\text { mg }\end{array}$ & $\begin{array}{c}\text { 複 } \\
\text { 合 } \\
\text { ゲ } \\
\text { 酸 } \\
\mathrm{mg}\end{array}$ & $\begin{array}{c}\text { 全 } \\
\text { ゲ } \\
\text { 酸 } \\
\mathrm{mg}\end{array}$ \\
\hline & 1 & $13 / \mathrm{VII}$ & 21.0 & \begin{tabular}{|c|}
2 \\
4 \\
合計
\end{tabular} & $\begin{array}{l}8.4 \\
7.6\end{array}$ & $\mid \begin{array}{r}6.5 \\
59.0 \\
65.5\end{array}$ & $\begin{array}{l}0.36 \\
3.06 \\
3.42\end{array}$ & $\begin{array}{l}0.85 \\
3.10 \\
3.95\end{array}$ & $\begin{array}{l}1.21 \\
6.16 \\
7.37\end{array}$ \\
\hline & 2 & 7/MII & 0.1 & $\left|\begin{array}{c}2 \\
4 \\
\text { 合計 }\end{array}\right|$ & $\begin{array}{l}6.6 \\
6.0\end{array}$ & $\left|\begin{array}{l}13.0 \\
12.5 \\
25.5\end{array}\right|$ & $\begin{array}{l}1.32 \\
3.75 \\
5.07\end{array}$ & $\begin{array}{l}0.15 \\
0.37 \\
0.52\end{array}$ & $\begin{array}{l}1.47 \\
4.12 \\
5.59\end{array}$ \\
\hline & 1 & $16 / \mathrm{VI}$ & 4.0 & $\mid \begin{array}{c}2 \\
4 \\
\text { 合計 }\end{array}$ & $\begin{array}{l}7.0 \\
6.8\end{array}$ & $\begin{array}{r}7.5 \\
8.8 \\
16.3\end{array}$ & $\begin{array}{l}1.37 \\
5.40 \\
6.77\end{array}$ & $\begin{array}{l}0,- \\
0.93 \\
0.93\end{array}$ & $\begin{array}{l}1.37 \\
6.33 \\
7.70\end{array}$ \\
\hline & 2 & 8/VII & 29.0 & $\mid \begin{array}{c}2 \\
4 \\
\text { 合棓 }\end{array}$ & $\begin{array}{l}6.4 \\
6.6\end{array}$ & \begin{tabular}{|r|}
4.1 \\
8.5 \\
12.6
\end{tabular} & $\begin{array}{l}1.13 \\
1.71 \\
2.84\end{array}$ & $\begin{array}{l}0.55 \\
0.27 \\
0.82\end{array}$ & $\begin{array}{l}1.68 \\
1.98 \\
3.66\end{array}$ \\
\hline & 1 & $30 / \mathrm{VII}$ & 29.0 & $\mid \begin{array}{c}2 \\
4 \\
\text { 合計 }\end{array}$ & $\begin{array}{l}7.0 \\
6.8\end{array}$ & $\begin{array}{l}14.0 \\
25.0 \\
39.0\end{array}$ & $\begin{array}{l}0.32 \\
1.41 \\
1.73\end{array}$ & $\begin{array}{l}0.05 \\
2.05 \\
2.10\end{array}$ & $\begin{array}{l}0.37 \\
3.46 \\
3.83\end{array}$ \\
\hline & 2 & 11/VII & 30,0 & \begin{tabular}{|c|}
2 \\
4 \\
合計
\end{tabular} & $\begin{array}{l}6.6 \\
6.2\end{array}$ & $\mid \begin{array}{r}3.7 \\
9.0 \\
12.7\end{array}$ & $\begin{array}{l}0.26 \\
2.62 \\
2.88\end{array}$ & $\begin{array}{l}0.70 \\
0.45 \\
1.15\end{array}$ & $\begin{array}{l}0.96 \\
3.07 \\
4.03\end{array}$ \\
\hline 1 & 1 & & 27.2 & $\left\{\begin{array}{l}\text { 合計 } \\
\text { 合計 }\end{array}\right.$ & & $\begin{array}{l}40.3 \\
16.9\end{array}$ & $\begin{array}{l}3.97 \\
3.60\end{array}$ & $\begin{array}{l}2.33 \\
0.83\end{array}$ & $\begin{array}{l}6.30 \\
4.43\end{array}$ \\
\hline
\end{tabular}

投与サ曹 : $500 \mathrm{mg}$ 
第 6 表

正常大尿中ゲ䙵量

夏季非固定の場合

\begin{tabular}{|c|c|c|c|c|c|c|c|c|c|}
\hline 堛 & 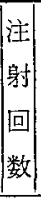 & $\begin{array}{c}\text { 実 } \\
\text { 験 } \\
\text { 月 } \\
\text { 日 }\end{array}$ & $\begin{array}{l}\text { 室 } \\
\text { 温 } \\
{ }^{\circ} \mathrm{C}\end{array}$ & $\begin{array}{l}\text { 与 } \\
\text { 後 } \\
\text { の } \\
\text { 時 } \\
\text { 間 } \\
h \\
h\end{array}$ & $\mathrm{pH}$ & $\begin{array}{l}\text { 尿 } \\
\text { 量 } \\
\text { cc }\end{array}$ & $\begin{array}{c}\text { 遊 } \\
\text { 離 } \\
\text { ゲ } \\
\text { 酸 } \\
\mathrm{mg}\end{array}$ & $\begin{array}{c}\text { 複 } \\
\text { 合 } \\
\text { ゲ } \\
\text { 酸 } \\
\mathrm{mg}\end{array}$ & $\begin{array}{c}\text { 全 } \\
\zeta^{*} \\
\text { mg }\end{array}$ \\
\hline & 1 & $19 / \mathrm{MII}$ & 30.0 & $\begin{array}{c}2 \\
4 \\
\text { 合計 }\end{array}$ & $\begin{array}{l}5.0 \\
6.4\end{array}$ & $\begin{array}{r}73.0 \\
54.0 \\
127.0\end{array}$ & $\begin{array}{l}. .31 \\
.27 \\
5.58\end{array}$ & $\begin{array}{l}2.07 \\
1.88 \\
3.95\end{array}$ & $\begin{array}{l}4.38 \\
5.15 \\
9.53\end{array}$ \\
\hline & 2 & 1/IX & 26.0 & $\mid$\begin{tabular}{r|}
2 \\
4 \\
合計
\end{tabular} & $\begin{array}{l}8.4 \\
7.4\end{array}$ & $\begin{array}{l}11.0 \\
19.0 \\
30.0\end{array}$ & $\begin{array}{l}.80 \\
.32 \\
.12\end{array}$ & $\begin{array}{l}0.25 \\
0.35 \\
0.60\end{array}$ & $\begin{array}{l}1.05 \\
1.67 \\
2.72\end{array}$ \\
\hline \multirow{2}{*}{16} & 1 & $25 / \mathrm{MII}$ & 26.0 & $\mid \begin{array}{c}2 \\
4 \\
\text { 合計 }\end{array}$ & $\left|\begin{array}{l}6.6 \\
6.6\end{array}\right|$ & $\begin{array}{l}67.0 \\
28.4 \\
95.4\end{array}$ & $\begin{array}{l}.73 \\
1.44 \\
.17\end{array}$ & $\begin{array}{l}0 .- \\
0.28 \\
0.28\end{array}$ & $\begin{array}{l}0.73 \\
1.72 \\
2.45\end{array}$ \\
\hline & 2 & 3/IX & 25.0 & $\left|\begin{array}{c}2 \\
4 \\
\text { 合計 }\end{array}\right|$ & $\left|\begin{array}{l}6.4 \\
6.4\end{array}\right|$ & $\begin{array}{r}20.0 \\
1.5 \\
21.5\end{array}$ & $\begin{array}{l}3.00 \\
0.52 \\
3.52\end{array}$ & $\begin{array}{l}0 .- \\
0.11 \\
0.11\end{array}$ & $\begin{array}{l}3.00 \\
0.63 \\
3.63\end{array}$ \\
\hline \multirow{2}{*}{13} & 1 & $10 / \mathrm{IX}$ & 30.0 & $\left|\begin{array}{c}2 \\
4 \\
\text { 合計 }\end{array}\right|$ & $\begin{array}{l}7.6 \\
7.4\end{array}$ & $\begin{array}{l}26.4 \\
18.8 \\
45.2\end{array}$ & $\begin{array}{l}0.28 \\
0.60 \\
0.88\end{array}$ & $\begin{array}{l}0.62 \\
0.55 \\
1.17\end{array}$ & $\begin{array}{l}0.90 \\
1.15 \\
2.05\end{array}$ \\
\hline & 2 & $22 / \mathrm{IX}$ & 28.0 & $\mid \begin{array}{c}2 \\
4 \\
\text { 合計 }\end{array}$ & $\begin{array}{l}5.6 \\
6.4\end{array}$ & $\begin{array}{l}64.0 \\
23.8 \\
87.8\end{array}$ & $\mid \begin{array}{l}1.35 \\
2.74 \\
4.09\end{array}$ & $\begin{array}{l}0 .- \\
0.42 \\
0.42\end{array}$ & $\begin{array}{l}1.35 \\
3.16 \\
4.51\end{array}$ \\
\hline \multirow{2}{*}{1} & 1 & $1 / X$ & $23.0 \mid$ & $\mid \begin{array}{c}2 \\
4 \\
\text { 合計 }\end{array}$ & $\begin{array}{l}4.8 \\
4.8\end{array}$ & $\begin{array}{l}22.0 \\
22.4 \\
44 .\end{array}$ & $\begin{array}{l}0.74 \\
1.90 \\
2.64\end{array}$ & $\begin{array}{l}0.29 \\
0.30 \\
0.59\end{array}$ & $\begin{array}{l}1.03 \\
2.20 \\
3.23\end{array}$ \\
\hline & 2 & $8 / X$ & 18.0 & 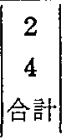 & $\begin{array}{l}6.0 \\
6.4\end{array}$ & $\begin{array}{l}24.2 \\
32.8 \\
57 .\end{array}$ & $\left|\begin{array}{l}0.36 \\
2.46 \\
2.82\end{array}\right|$ & $\begin{array}{l}0.17 \\
0.51 \\
0.68\end{array}$ & $\begin{array}{l}0.53 \\
2.97 \\
3.50\end{array}$ \\
\hline 平均 & $\begin{array}{l}1 \\
2\end{array}$ & & 25. & $\left\{\begin{array}{l}\text { 合計 } \\
\text { 合計 }\end{array}\right.$ & & $\begin{array}{l}78 \\
49\end{array}$ & $\begin{array}{l}2.82 \\
3.14\end{array}$ & $\begin{array}{l}1.50 \\
0.45\end{array}$ & $\begin{array}{l}1.32 \\
3.59\end{array}$ \\
\hline
\end{tabular}

投与サ曹 : $500 \mathrm{mg}$

い。即ち固定は尿中遊離ゲ酸量及複合ゲ酸量に大なる 影響を及ぼさない。然しなるへく自然の状態に於て動 物を㓋察する目的を以て以後は肝剔の場合を除き総て 採尿時以外は非固定のま小笑験を行つた。

iii）気温の影㗽

夏梩は高温の為犬の元気が衰えている。これらの影

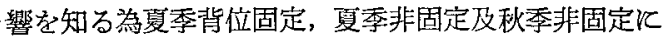
就き比較检傠した。成䋶は第 5，6，7 表の如し。
第 7 表

正常犬尿中ゲ酸量 秋李非固定の場合

\begin{tabular}{|c|c|c|c|c|c|c|c|c|c|}
\hline 天 & $\begin{array}{l}\text { 注 } \\
\text { 射 } \\
\text { 回 } \\
\text { 数 }\end{array}$ & $\begin{array}{c}\text { 実 } \\
\text { 験 } \\
\text { 月 } \\
\text { 日 }\end{array}$ & $\begin{array}{l}{ }^{\circ} \mathrm{C} \\
\text { 温 } \\
\end{array}$ & $\begin{array}{l}\text { 与 } \\
\text { 徯 } \\
\sigma \\
\text { 時 } \\
\text { 間 } \\
\mathrm{h}\end{array}$ & $\mathrm{pH}$ & $\begin{array}{l}\text { 舅 } \\
\mathrm{cc}\end{array}$ & $\begin{array}{c}\text { 遊 } \\
\text { 離 } \\
ケ ゙ \\
\text { ·酸 } \\
\text { mg }\end{array}$ & $\begin{array}{c}\text { 複 } \\
\text { 合 } \\
\text { ゲ } \\
\text { 酸 } \\
\mathrm{mg}\end{array}$ & $\begin{array}{l}\text { 全 } \\
\text { ゲ } \\
\text { 酸 } \\
\text { mg }\end{array}$ \\
\hline & 1 & $6 / X$ & 20.0 & $\mid \begin{array}{c}2 \\
4 \\
\text { 合計 }\end{array}$ & $\begin{array}{l}5.8 \\
5.6\end{array}$ & $\begin{array}{l}12.5 \\
10.0 \\
22.5\end{array}$ & $\begin{array}{r}3.12 \\
10.36 \\
13.48\end{array}$ & $\begin{array}{r}.29 \\
.59 \\
.88\end{array}$ & $\begin{array}{r}3.41 \\
11.95 \\
15.36\end{array}$ \\
\hline & 2 & $19 / X$ & 20.0 & $\mid \begin{array}{c}2 \\
4 \\
\text { 合計 }\end{array}$ & $\begin{array}{l}7.6 \\
7.2\end{array}$ & $\begin{array}{l}15.0 \\
24.4 \\
39.4\end{array}$ & $\begin{array}{l}1.77 \\
3.69 \\
5.46 \\
\end{array}$ & $\left|\begin{array}{l}0.35 \\
0.66 \\
1.01\end{array}\right|$ & $\begin{array}{l}2.12 \\
4.35 \\
6.47\end{array}$ \\
\hline & 1 & $15 / X$ & $17.0 \mid$ & $\mid \begin{array}{c}2 \\
4 \\
\text { 合計 }\end{array}$ & $\begin{array}{l}6.0 \\
5.6\end{array}$ & $\begin{array}{r}8.0 \\
10.0 \\
18.0\end{array}$ & $\begin{array}{l}3.21 \\
5.54 \\
8.75\end{array}$ & $\left|\begin{array}{l}0.15 \\
0.83 \\
0.98\end{array}\right|$ & $\begin{array}{l}3.36 \\
6.37 \\
9.73\end{array}$ \\
\hline & 2 & $23 / X$ & 19.0 & $\left|\begin{array}{c}2 \\
4 \\
\text { 合計 }\end{array}\right|$ & $\begin{array}{c}6.0 \\
5.6 \\
\end{array}$ & $\begin{array}{l}30.0 \\
14.6 \\
44.6\end{array}$ & $\begin{array}{l}1.23 \\
3.04 \\
4.27\end{array}$ & $\mid \begin{array}{l}0 .- \\
0 .- \\
0 .-\end{array}$ & $\begin{array}{l}1.25 \\
3.04 \\
4.27\end{array}$ \\
\hline & 1 & $27 / X$ & 18.0 & $\left|\begin{array}{c}2 \\
4 \\
\text { 合計 }\end{array}\right|$ & $\left|\begin{array}{l}6.4 \\
6.2\end{array}\right|$ & $\begin{array}{l}24.2 \\
68.0 \\
92 \cdot 2\end{array}$ & $\begin{array}{r}3.03 \\
9.75 \\
12.78\end{array}$ & $\begin{array}{l}0.67 \\
3.42 \\
4.09\end{array}$ & $\begin{array}{r}3.7 \\
13.17 \\
16.87\end{array}$ \\
\hline & 2 & $3 / \mathrm{XI}$ & 18.0 & $\left|\begin{array}{c}2 \\
4 \\
\text { 合計 }\end{array}\right|$ & $\begin{array}{l}6.2 \\
6.2\end{array}$ & $\begin{array}{r}65.0 \\
78.0 \\
143.0\end{array}$ & $\begin{array}{l}1.87 \\
5.92 \\
7.79\end{array}$ & $\mid \begin{array}{l}0.83 \\
2.78 \\
3.61\end{array}$ & $\begin{array}{r}2.70 \\
8.70 \\
11.40\end{array}$ \\
\hline & 1 & $29 / X$ & 20.0 & 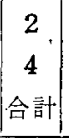 & $\begin{array}{l}7.2 \\
6.4\end{array}$ & $\begin{array}{r}8.5 \\
15.0 \\
23.5\end{array}$ & $\begin{array}{l}1.64 \\
2.62 \\
4.26\end{array}$ & $\begin{array}{l}0.15 \\
0.53 \\
0.68\end{array}$ & $\begin{array}{l}1.79 \\
3.15 \\
4.94\end{array}$ \\
\hline & 2 & 4/XI & 18.0 & 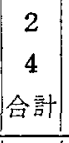 & $\left|\begin{array}{l}8.6 \\
8.0\end{array}\right|$ & $\begin{array}{r}6.5 \\
8.5 \\
15.0\end{array}$ & $\begin{array}{l}1.03 \\
2.55 \\
3.58 \\
\end{array}$ & $\mid \begin{array}{l}0.31 \\
0.35 \\
0.66\end{array}$ & $\begin{array}{l}1.34 \\
2.90 \\
4.24\end{array}$ \\
\hline & 1 & $30 / X$ & 19.0 & 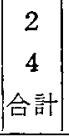 & $\begin{array}{l}7.6 \\
7.6\end{array}$ & $\begin{array}{l}28.0 \\
24.8 \\
52.8\end{array}$ & $\begin{array}{l}2.44 \\
5.09 \\
7.53\end{array}$ & $\mid \begin{array}{l}0.55 \\
0.82 \\
1.37\end{array}$ & $\begin{array}{l}2.99 \\
5.91 \\
8.90\end{array}$ \\
\hline & 2 & 5/XI & 18.0 & 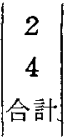 & $\begin{array}{l}6.8 \\
6.2\end{array}$ & $\begin{array}{r}5.6 \\
9.8 \\
15.4\end{array}$ & $\begin{array}{l}2.16 \\
1.64 \\
3.80\end{array}$ & $\mid \begin{array}{l}0.05 \\
1.10 \\
1.15\end{array}$ & $\begin{array}{l}2.21 \\
2.74 \\
4.95\end{array}$ \\
\hline \begin{tabular}{|l} 
平 \\
均 \\
僆
\end{tabular} & 1 & & 18. & 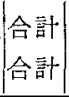 & & $\begin{array}{l}41.8 \\
51.5\end{array}$ & $\begin{array}{l}9.36 \\
4.98\end{array}$ & $6\left|\begin{array}{l}1.80 \\
1.29\end{array}\right|$ & $\begin{array}{r}11.1 \\
6.2\end{array}$ \\
\hline
\end{tabular}

投与サ曹 : $500 \mathrm{mg}$ 


$$
-56-(350)
$$

遊離ゲ酸の夏季背位固定及夏李非固定の平均値は秋 季非固定平均值に比乙初回份荷時及再度真荷時共に少 い。複合ゲ酸の夏李背位固定及夏季非固定平均值は秋 季非固定平均值に比し，夏季背位固定初回目荷時が僅 に多い以外は初回負荷時及再度負荷時共に少い。即ち 堂温は尿中遊離ゲ酸量及複合ゲ酸量共に減少せしめ る。因みに夏季背位固定の平均室温 $27.2^{\circ} \mathrm{C}$, 夏季非固 定 $25.8^{\circ} \mathrm{C}$, 秋季非固定 $18.7^{\circ} \mathrm{C}$ であつた。

以上を総合して考按するに，夷験はサ糞初回目荷時 のみとし，䯩温時を避けて行うことが尿中ゲ酸量の研 究には重要であると考える。

\section{b）尿中ゲ酸量の正常値}

上記諸種のことがらから尿中ゲ酸量を研究せんとす る時は条件を秋李サ曹初回負荷時と限定して実験する が便である。この場合の尿中ゲ酸量の正常範囲を笑験 時正常値と名付けた。又尿中ゲ酸量の定量を応用し臟

$$
\text { 第 } 8 \text { 表 }
$$

橗障碍犬㲾中ゲ酸墨

\begin{tabular}{|c|c|c|c|c|c|c|c|}
\hline $\begin{array}{l}犬 \\
\text { 番 } \\
\text { 号 }\end{array}$ & $\begin{array}{l}\text { 室 } \\
\text { 温 } \\
{ }^{\circ} \mathrm{C}\end{array}$ & $\begin{array}{l}\text { 投 } \\
\text { 热 } \\
\text { 後 } \\
0 \\
\text { 時 } \\
\text { 間 } \\
\mathrm{h} \\
\end{array}$ & $\mathrm{pH}$ & $\begin{array}{l}\text { 尿 } \\
\text { 量 } \\
\text { cc }\end{array}$ & $\begin{array}{c}\text { 遊 } \\
\text { 離 } \\
\text { ゲ } \\
\text { mg }\end{array}$ & $\begin{array}{l}\text { 複 } \\
\text { 合 } \\
\text { ゲ } \\
\text { 酸 } \\
\text { mg }\end{array}$ & $\begin{array}{c}\text { 全 } \\
\text { ゲ } \\
\text { 酸 } \\
\mathrm{mg}\end{array}$ \\
\hline 26 & 14.0 & $\begin{array}{c}2 \\
4 \\
\text { 合計 }\end{array}$ & $\begin{array}{l}8.4 \\
7.4\end{array}$ & $\begin{array}{l}21.0 \\
17.4 \\
38.4\end{array}$ & $\begin{array}{l}0.41 \\
1.37 \\
1.78\end{array}$ & $\begin{array}{l}0.38 \\
0 .- \\
0.38\end{array}$ & $\begin{array}{l}0.79 \\
1.37 \\
2.16\end{array}$ \\
\hline 31 & 16.0 & $\begin{array}{c}2 \\
4 \\
\text { 合計 }\end{array}$ & $\begin{array}{l}5.8 \\
5.8\end{array}$ & $\begin{array}{l}12.0 \\
12.0 \\
24.0\end{array}$ & $\begin{array}{l}2.89 \\
2.97 \\
5.86\end{array}$ & $\begin{array}{l}0.05 \\
0.15 \\
0.20\end{array}$ & $\begin{array}{l}2.94 \\
3.12 \\
6.06\end{array}$ \\
\hline 32 & 14.0 & $\begin{array}{c}2 \\
4 \\
\text { 合計 }\end{array}$ & $\begin{array}{l}6.6 \\
5.8\end{array}$ & $\begin{array}{r}25.2 \\
101.0 \\
126.2\end{array}$ & $\begin{array}{l}2.02 \\
3.95 \\
5.97\end{array}$ & $\begin{array}{c}0.28 \\
0.56 \\
0.84\end{array}$ & $\begin{array}{l}2.30 \\
4.51 \\
6.81\end{array}$ \\
\hline 33 & 18.0 & $\begin{array}{c}2 \\
4 \\
\text { 合計 }\end{array}$ & $\begin{array}{l}6.6 \\
7.0\end{array}$ & $\begin{array}{l}34.4 \\
11.4 \\
45.8\end{array}$ & $\begin{array}{l}1.01 \\
0.54 \\
1.55\end{array}$ & $\begin{array}{l}0 .- \\
0 .- \\
0 .-\end{array}$ & $\begin{array}{l}1.01 \\
0.54 \\
1.55\end{array}$ \\
\hline 34 & 18.0 & $\begin{array}{c}2 \\
4 \\
\text { 合計 }\end{array}$ & $\begin{array}{l}5.6 \\
5.6\end{array}$ & $\begin{array}{l}12.6 \\
11.4 \\
24.0\end{array}$ & $\begin{array}{l}1.40 \\
1.92 \\
3.32\end{array}$ & $\begin{array}{l}0.15 \\
0.45 \\
0.60\end{array}$ & $\begin{array}{l}1.55 \\
2.37 \\
3.92\end{array}$ \\
\hline 均值 & 16.0 & 合計 & & 51.7 & 3.70 & 0.40 & 4.10 \\
\hline
\end{tabular}

秋及初冬非固定の場合

実験月日：自 11 月 18 日 至 12 月 23 日 注射回数：全例 1 回，投与サ曹：500 mg 肝障碍法：四塩化炭素 $0.5 \mathrm{cc} / \mathrm{kg}$ 皮下注射 (肝障碍後 24 時間江て実験開始)
器の機能検查等に資せんとする時は動物の被る条件を 規定出来ない事が多い。故にあらゆる場合を含九だ尿 中ゲ酸量の正常範囲を応用時正常值上名付けた。

奏験時正常侣：(秋季非固定开曹初回目荷) 4 時間 総量に於て遊離ゲ酸量は 4.26-13.48 mg（負荷サ曹の 0.85-2.70\%）複合ゲ酸望は 0.68-4.09 mg（0.14$0.82 \%$ )である。

応用時正常値：（夏季背位固定, 夏季非固定及秋季 非固定の初回負荷及再度負荷） 4 時間総量に於て遊離 ゲ酸量は 0.88-13.48mg $(0.18-2.70 \%$ ) 複合ゲ酸量は 0-4.09 mg (0-0.82,6) である。

実験時正常遊離ゲ酸量の夕略一定しているが其他は 一定しない。

c）尿の性状と尿中ゲ酸量との関係

i） サ曹注射後採尿迄の時間と㽷中ゲ酸量

遊離ゲ酸は 24 例中 22 例，複合ゲ酸は 24 例中 19 例《於て注射後最初の 2 時間尿よりる後の 2 時間尿の 方が多量であつた。

ii）尿量及尿の $\mathrm{pH}$ と尿中ゲ酸量

遊離ゲ酸量及複合ゲ酸量共に尿量及尿の $\mathrm{pH}$ との間 に一定の関係は得られなかつた。

\section{3）䀒障碍犬尿中ゲ酸量}

四塩化炭素 $0.5 \mathrm{cc} / \mathrm{kg}$ 皮下注射して朋障码し， 24 洔間後曹初回注射を行い採尿時以外は非固定のま〉 にて実験を行つた。気温は秋季及初冬, 平均温度 $16.0^{\circ} \mathrm{C}$ の適温であつた。成纈は第 8 表に示す。

このゲ酸量を秋季非固定初回負荷の場合と比較する と，平均值に於ては遊離ゲ酸 量は $1 / 2$ 以下に，複合 ゲ酸量は 1/4以下に著明に減少している。各例につい :てる例外ばるが大体この事が言える。

\section{4) 䀒剔出犬尿中ゲ酸量}

一次的肝剔出法 ${ }^{22}$ 亿依り肝藏を剔出し，直ちにサ 蓸初回注射し, 後処置として $25 \%$ 葡萄糖溶液 $20 \mathrm{cc}$ を 1 時間每に静脈注射し，技術上非圆定のま口㓋察す る事は不可能であり，且つ正常例の㬰験により固定は 尿中ゲ酸量に影響を及ぼさぬものと考えられるので固 定のま」実験を行つた。気温は秋季平均温度 $15.4^{\circ} \mathrm{C}$ の適温であつた。成績は第 9 表に示す。

5 例中 4 例は遊離ゲ酸複合ゲ酸共に皆無で问好整物

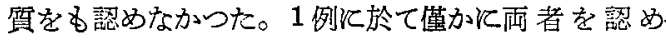
た。然しこれとても遊離ゲ酸量は他の実験に於て認め 得なかつつた程の微量であり，複合ゲ酸量る平坞值は他， の奏験より僅少であつた。 


\section{IV) 総括並に考按}

能勢は従来のゲ酸定量法を検討乙，これを尿応用 する為にはいずれる高度の技術を要するか又は妨害物 筫の充分な除去が必要なる事を認め，燐モりブデン酸 を用いる新方法を報告し，これを人及家躳に就き応用 した。私は犬尿に就きうの方法を検討したが妨害物貝 多量の為犬飞於ては他の方法を用いね济ならない事を 知つた。Lutwak-mann はサ酸塭注射後のラット尿に 苛曹溶液を滴下寸ると褐色より黑色火変化する物質の ある事に著目し，これがゲ酸なる事を認めた。更隹氏

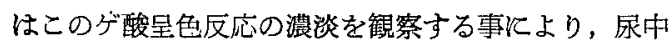
ゲ酸の多䕓を推定した。而しこのゲ酸呈色反応は赤色 より褐色焠色してゆく不安定なものであり，そのま ১では比色定量沉応用する事は出来ないので, 私はこ のゲ酸呈色反応が各条件下涀はす色語変化の性躓を 検討し，その安定となるべき条件を見出し，これを基 として $1 \mathrm{M}$ 苛曹溶液深よる犬尿中方酸定量法を考案

\section{第 9 表}

肝剔犬尿中ゲ酸量 秋季固定の場合

\begin{tabular}{|c|c|c|c|c|c|c|c|}
\hline $\begin{array}{l}\text { 犬 } \\
\text { 番 } \\
\text { 号 }\end{array}$ & $\begin{array}{l}\text { 室 } \\
\text { 温 } \\
{ }^{\circ} \mathrm{C}\end{array}$ & $\begin{array}{l}\text { 投 } \\
\text { 兮 } \\
\text { 㣪 } \\
9 \\
\text { 時 } \\
\text { 間 } \\
\mathrm{h}\end{array}$ & $\mathrm{pH}$ & $\begin{array}{l}\text { 尿 } \\
\text { 量 } \\
\mathrm{cc}\end{array}$ & $\begin{array}{l}\text { 遊 } \\
\text { 離 } \\
\text { ゲ } \\
\text { 酸 } \\
\mathrm{mg}\end{array}$ & $\begin{array}{l}\text { 複 } \\
\text { 合 } \\
\text { ゲ } \\
\text { 酸 } \\
\text { mg }\end{array}$ & $\begin{array}{l}\text { 全 } \\
\text { ゲ } \\
\text { 酸 } \\
\mathrm{mg}\end{array}$ \\
\hline 23 & 17.0 & $\begin{array}{c}2 \\
4 \\
\text { 合計 }\end{array}$ & $\begin{array}{l}6.2 \\
6.2\end{array}$ & $\begin{array}{l}49.0 \\
14.2 \\
63.2\end{array}$ & $\begin{array}{l}0 .- \\
0 .- \\
0 .\end{array}$ & $\begin{array}{l}0 .- \\
0 .- \\
0 .-\end{array}$ & $\begin{array}{l}0 .- \\
0 .- \\
0 .-\end{array}$ \\
\hline 24 & 18.0 & $\begin{array}{c}2 \\
4 \\
\text { 合計 }\end{array}$ & $\begin{array}{l}6.8 \\
6.6\end{array}$ & $\begin{array}{l}17.9 \\
17.2 \\
35.1\end{array}$ & $\begin{array}{l}0 .- \\
0 .- \\
0 .-\end{array}$ & $\begin{array}{l}0 .- \\
0 .- \\
0 .-\end{array}$ & $\begin{array}{l}0 .- \\
0 .- \\
0 .-\end{array}$ \\
\hline 25 & 14.0 & $\begin{array}{c}2 \\
4 \\
\text { 合計 }\end{array}$ & $\begin{array}{l}8.2 \\
7.4\end{array}$ & $\begin{array}{l}27.6 \\
14.2 \\
41.8\end{array}$ & $\begin{array}{l}0 .- \\
0 .- \\
0 .-\end{array}$ & $\begin{array}{l}0 . \\
0 . \\
0 .\end{array}$ & $\begin{array}{l}0 .- \\
0 .- \\
0 .-\end{array}$ \\
\hline 28 & 12.0 & $\begin{array}{c}2 \\
4 \\
\text { 合計 }\end{array}$ & $\begin{array}{l}6.6 \\
6.2\end{array}$ & $\begin{array}{r}74.0 \\
7.2 \\
81.2\end{array}$ & $\begin{array}{l}0 .- \\
0 .- \\
0 .\end{array}$ & $\begin{array}{l}0 .- \\
0 .- \\
0 .-\end{array}$ & $\begin{array}{l}0 . \\
0 .- \\
0 .-\end{array}$ \\
\hline 30 & 16.0 & $\begin{array}{c}2 \\
4 \\
\text { 合計 }\end{array}$ & $\begin{array}{l}7.4 \\
6.8\end{array}$ & $\begin{array}{l}26.6 \\
41.0 \\
67.6\end{array}$ & $\begin{array}{l}0.01 \\
0.01 \\
0.02\end{array}$ & $\begin{array}{l}0 .- \\
0.26 \\
0.26\end{array}$ & $\begin{array}{l}0.01 \\
0.27 \\
0.28\end{array}$ \\
\hline 均値 & 15.4 & 合計. & & 57.8 & $0 .-$ & 0.05 & 0.06 \\
\hline
\end{tabular}

実駼月日：自 11 月 11 日 至 12 月 2 日 注射回数：全例 1 回, 投与世曹 : $500 \mathrm{mg}$
した。即ち被検尿を酸性下江 10 喿燐タングステン酸 及 10\%醋酸鈶にて妨害物質を除去し，上清をエーテル 飞て強振温し，エーテル相及尿相に分つ。エーテル相 より $1 \mathrm{M}$ 苛曹溶液沉て遊離ゔ酸を振溘抽出同時飞呈 色せしめ，これを 16-20ㅇ，40-50 分放置し色調安定 となつた時比色定量す。これより妨害物筫值を差引 き遊離ゲ酸量となす。複合ゲ酸は尿相を 30 分沸滕温 浴, 室温放置冷却後遊離ら゙酸と同㥞比して定量する。 本定量法の検出率は実用化供し得る正確度を有する事 を確かめた。本定量法を用いて犬に就き実験せると次 の如き結果を得た。

1）サ曹初回目荷時は再度負荷時より尿中遊離ゲ酸 量, 複合ゲ酸量共概して多量であつた。

2）固定は尿中遊離ゲ酸量，複合ゲ酸量飞大なる影 響を及ぼさなかつた。

3）適温時は高温時上り永中遊離ら゙酸量は著明江多 量, 複合ゲ酸量は概して多量であつた。即ち犬尿中ゲ 酸量汇関する研究を行うには州曹初回負荷時意選び高 温時を避けて施行すべきである。

4） サ曹注射後最初の 2 時間尿よりも後の 2 時間尿 の方が遊離ゲ酸量, 複合ゲ酸量共に多からた。

5）肝障碍時性秋季非固定初回負荷平均値比比し避 離ゲ酸量, 複合ゲ酸量共に著明に減少す。各例につい ても大体この事が言える。

6）盰剔出時は遊離ゲ酸，複合づ酸共に殆ど消失し た。即ちザ酸を避離ゲ酸及複合ゲ酸に変化せしめる機 能は肝の関与するところ極めて大である。

7)尿中グ酸量は犬に対する条件が不適当な時，例

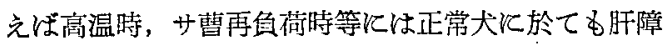
碍犬と選ぶ所無き迄減少するものであるから，尿中ゲ 酸量を定量して肝機能検查が常汇可能なりとは言い難 w。

\section{V) 結 論}

1）ゲ酸呈色反応を検討し，1 $\mathrm{M}$ 苛曹溶液を用いて 大尿中ゲ酸を定量する方法を見出した。

2）本定量法を用い，正常，肝障碍，肝剔出犬尿中 ゲ酸を定量, 比較検討し，尿中ゲ酸は肝の関与すると ころ極めて大であるが，この定量による肝機能検查は 常に可能とは言い難い。

(本論交の要旨は第 10 回日本楽理学会関東部会て 発表した。) 


\section{引用 文 献}

1) Kleckner : J. Ann. Pharm. Assoc., 41, 103 (1952)

2) Angelico: Arch. farm. sper., 31, 8 (1921)

3) Neuberg : Berl. klin.'Wschr., 38, 798 (1911)

4) Alpen : J. Pharmacol. Exptl. Therap., 102, 150 (1951)

5) Roseman : J. Biol. Chem., 192,105 (1951)

6) Quilley : J. Pharm. Pharmacol., 4, 624 (1952)

7) Lutwak-mann : Biochem. J., 37, 246 (1943)

8) Kapp : J. Biol. Chem., 145, 549 (1942)

9) 稲垣成男:日医大誌, 19,977 (1952)

10) Accoyer : Ann. Pharm. franc., 7, 746 (1949) C.A.より

11) Mendioroz: Arch. soc. biol., 19,97 (1952) C.A. より
12) Gerald : J. Biol. Chem., 189, 467 (1951)

13) Lowenthal : J. Lob. Clin. Med., 38, 916 (1951)

14) Benati : Farm. sci. e tec., 5, 43 (1950) C. A. 上

15) Mainardi : Boll. soc. ital. biol. sper., 26, 580 (1950) C.A.より

16) Smith : J. Pharm. Pharmacol., 2, 439 (1950) C.A.より

17) Folin : J. Biol. Chem., 73, 627 (1927)

18) Ungar: Proc. Soc. Expt1. Biol. Med,, 80, 45 (1952) C.A. より

19) Nanninga : Nature., 168, 389 (1951)

20) Rutkowski : Arzneimittel-Forschung, 3, 209 (1954)

21）能勢勇一: 生化学, 26, 32 (1954)

22) 西村菊次郎：東京医会誌，50，1035 (1936) 